\section{Have You Seen This? Why Political Pundits Share Scholarly Research on Social Media}

\author{
David R.H. Moscrop \\ University of Ottawa
}

Lorriane Wong

Western University

Juan Pablo Alperin

Simon Fraser University
Scholarly and Research

Communication

VOLUME 11 / ISSUE 1 / 2020

\begin{abstract}
Background A healthy public sphere requires a flow of reliable, trustworthy, and accurate information. Scholarly research is one such source but, to be most effective, it must reach the public. One possible dissemination route for that material is political pundits.
\end{abstract}

Analysis We extracted the tweets of thirty-two Canadian pundits with links to scholarly research and studied the main motivations for sharing a link to a scholarly article.

Conclusion and implications We found that most pundits we studied tweeted at least one link to a scholarly article and that the motivations for sharing varied. However, our sample shared links to scholarly journal articles infrequently.

Keywords Altmetrics; Social media; Pundits; Motivation; Canadian politics

\section{Résumé}

Contexte Pour bien fonctionner, une sphère publique requiert un flux d'informations qui soient fiables, dignes de confiance et précises. La recherche savante est une source de telles informations, mais pour être efficace elle doit rejoindre le public. Une façon de disséminer la recherche consiste à recourir à des commentateurs politiques.

Analyse Nous avons passé en revue les gazouillis de 32 commentateurs canadiens ayant des liens avec la recherche savante et nous avons étudié leurs motivations principales pour partager un lien vers un article savant.

CISP Journal Services

Scholarly and Research Communication

Volume 11, Issue 1, Article ID 0101355, 21 pages

Journal URL: www.src-online.ca https://doi.org/10.22230/src.2020v11n1a355

Received January 10, 2020, Accepted May 2, 2020, Published May 26, 2020

Moscrop, David R.H., Wong, Lorraine, \& Alperin, Juan Pablo. (2020). Have You Seen This? Why Political Pundits Share Scholarly Research on Social Media. Scholarly and Research Communication, 11(1): 0101355, $21 \mathrm{pp}$.

(C) 2020 David R.H. Moscrop, Lorraine Wong, \& Juan Pablo Alperin. This Open Access article is distributed under the terms of the Creative Commons Attribution Non-Commercial License (http:// creativecommons.org/licenses/by-nc-nd/2.5/ca), which permits unrestricted non-commercial use, distribution, and reproduction in any medium, provided the original work is properly cited.
David R.H. Moscrop is a SSHRC postdoctoral fellow in the Department of Communication at the University of Ottawa. Email: dmoscrop@uottawa.ca

Lorraine Wong is a doctoral candidate in the LIS PhD Program at Western University studying why people are motivated to share news and non-personal content on social media. Email: lola.wong@uwo.ca

Juan Pablo Alperin is an Assistant Professor at the School of Publishing at Simon Fraser University, the Associate Director of Research for the Public Knowledge Project, the codirector of the Scholarly Communications Lab, and corresponding author. Email: juan@alperin.ca 


\section{Scholarly and Research}

\section{Communication}

VOLUME 11 / ISSUE 1 / 2020
Conclusion et implications Nous avons découvert que la plupart des commentateurs de notre échantillon ont inclus au moins un lien vers un article savant dans leurs gazouillis et que leurs motivations pour le faire étaient diverses. Cependant, ces commentateurs ne partageaient pas souvent des liens vers des articles paraissant dans des revues savantes.

Mots clés Métriques alternatives; Médias sociaux; Commentateurs; Motivation; Politique canadienne

\section{Introduction}

Contemporary liberal democracy is premised on the idea that citizens ought to have a say in how they are governed. This commitment implies an empowering of citizens to self-govern based on the all affected interests principle (AAIP): individuals ought to have a say in public decisions that affect their lives (Fung, 2013; Habermas, 1996; Young, 2000). Mark Warren (2017) characterizes the principle as expressing "a very basic intuition about what democracy is good for" (p.1), namely that "With [it], I am part of networks of co-dependents who can collectively self-determine and provide opportunities for self-development ... Without it, I am likely to be subject to forces over which I have little or no control" (p. 1). The AAIP, however, implies not only a right to participate in collective self-determination but also the need for a robust public sphere - a shared space in which the work of self-determination, preference formation, and communication can be done (Habermas, 1984, 1989; Schudson, 1998). The public sphere runs on information; if individuals are to form reasons for preferences, the content of those reasons ought to include reliable information that can be collected, processed, and shared with others.

In recent years, a digital or virtual public sphere has emerged in which citizens engage in political exchanges that are roughly comparable to what we would expect to see in the face-to-face world of the analogue public sphere (Dahlberg, 2001; Dahlgren, 2005; Schäfer, 2015). Social media platforms serve as one of the spaces in which individuals can do that work or "gather publicly through mediating technology," (Hermida, Fletcher, Korell, \& Logan, 2012, p. 2) as the authors put it, referring to this space as a networked public sphere (this term will hereafter be used for this digital public space). Twitter, one of the leading social media platforms in the networked public sphere and the focus of the study, is a major hub for the collection and sharing of information. Twitter is a major source for news consumption (Purcell, Rainie, Mitchell, Rosenstiel, \& Olmstead, 2010; Smith \& Rainie, 2010). Yet, despite mass activity on Twitter and other sites, participation in these spaces is neither universal nor randomly distributed.

The networked sphere also differs from the traditional public sphere in that information is available from a much wider set of individuals and is more readily available than it was prior to the development of the internet and social media. As a result, much as in the traditional public sphere, some citizens turn to trusted sources and individuals for guidance in information they should pay attention to. Even the media itself, as it operates in both the traditional and digital public spheres, relies on trusted sources and individuals - often in the form of scientific research and pundits - to lend credibility to their reporting and to assert their value as providers of important and reliable information to the public. What is different, however, is that the networked or digital public 
sphere allows anyone, including the same pundits called on by traditional media companies, to share information, such as scholarly research, directly with the public through social media channels. The opening of media platforms to the public, beyond the traditional gatekeeping limits of newspapers or newscasts, has at once created new spaces of engagement and information dissemination while also lowering the standards of quality assessment for some types of information.

The digital public sphere offers a unique opportunity for the high-quality expert knowledge contained in scholarly publications to reach both policymakers and ordinary citizens. As altmetrics, an emerging field of research evaluation, discovers ways to measure the extent to which research circulates on social media (Priem, Taraborelli, Groth, \& Neylon, 2010; Sugimoto, Work, Larivière, \& Haustein, 2017), this article takes a first step in examining the role of prominent and relied-upon individuals - political pundits - and their contribution to political life in the digital public sphere through promoting academic work. Examining a small sample of Canadian political pundits, this article asks: Do political pundits share scholarly research? If yes, why are they motivated to do so? The study focuses on Twitter because it is a mass public social media platform frequently used by political pundits and by individuals who seek news and information online (Hermida et al., 2012; Olmstead, Mitchell, \& Rosenstiel, 2011).

\section{Background}

\section{Punditry AND THE PUBlic SPHERE}

There is no consensus on who counts as a pundit; other terms, including commentator, columnist, writer, opinion leader, and even public intellectual, are sometimes used interchangeably (Dahlgren, 2013). Arthur Melzer, Jerry Weinberger, and Richard Zinman (2003) use the term "public intellectual" in such a way that "pundit" fits comfortably: "A class of hybrid beings standing with one foot in the contemplative world and the other in the political" (p.xi). Posner (2001) provides a similar general category, with the public intellectual as someone who "opine[s] to an educated public on questions of or inflected by a political or ideological concern" (p. 2). Richard Posner (2001) deliberately narrows the definition from one who applies "ideas to matters of broad public concern" (p. 18) to distinguish between intellectuals and public intellectuals. Thus, for Posner, the public intellectual writes on political matters, broadly conceived. As the academic world changes and more scholars are invited and incentivized into public media spaces, however, this conceptualization may require a rethink.

Notwithstanding the discussion about who counts as a public intellectual, pundit, and so forth, this article attempts to minimize confusion and avoid triggering the common assumption that "intellectual" is synonymous with "academic" by using the term "pundit" broadly while bracketing (legitimate) debates about who counts as what under which circumstances. This study uses the Oxford English Dictionary (2017) definition of "pundit," which fits well with the common usage and understanding of the term: "An expert in a particular subject or field who is frequently called upon to give their opinions to the public." Political columnists are included as experts, given the function these individuals serve in informing the public about political issues and providing commentary on those issues. 


\section{Scholarly and Research}

\section{Communication}

VOLUME 11 / ISSUE 1 / 2020
Pundits serve as public sphere intermediaries, circulating information required for individuals to make informed judgements and to self-represent under the auspices of the AAIP - even if that information is not taken up by or accessible to an entire population. This research asks if one of the ways pundits serve within the public sphere is by bringing scholarly research published by academics to a broader audience than the academic community. Preliminary work from the field of altmetrics suggests that research on social media is largely shared by and among academics (Haustein \& Costas, 2015; Tsou, Bowman, Ghazinejad, \& Sugimoto, 2015), but that, with the help of intermediaries, scholarly research can be brought to more diverse communities (Alperin, Gomez, \& Haustein, 2018). Pundits may serve this intermediary role; this study is an initial step in examining whether and to what extent they do, and why.

\section{Motivations}

What would motivate a pundit to share academic material? Motivation refers to an energization or direction of behaviour (Elliot \& Covington, 2001; Hew \& Hara, 2007). A number of studies have examined what motivates individuals to engage with others and to share information online, including sharing links and material on Facebook (Baek, Holton, Harp, \& Yaschur, 2011), Twitter (Chen, 2011; Holton, Baek, Coddington, \& Yaschur, 2014; Papacharissi, 2012), in virtual communities (Chiu, Hsu, \& Wang, 2006; Lai \& Chen, 2014; Lin, 2006), by specialists in online communities (Hara \& Foon Hew, 2007), and across the internet and social media in general (Boulianne, 2009; Hermida et al., 2012; Hew \& Hara, 2007; Ho \& Dempsey, 2010; Lee \& Ma, 2012; Lin \& Lu, 2011; Oh \& Syn, 2015; The New York Times Customer Insight Group, 2011; Wong \& Burkell, 2017). Motivations to share research should also be considered with regards to the level of engagement required of the individual who comes across a document, whereas sharing research on Twitter is seen as an act of appraisal, requiring less engagement than the act of applying the content of the research (Haustein, Bowman, \& Costas, 2016). However, motivation typologies are difficult to assess, sort, and harmonize since there are significant temporal and depth variations across and within typologies. There are also levels of motivation, including intrinsic, extrinsic, and community motivation types (Lai \& Chen, 2014). Furthermore, some motivation categories speak to immediate considerations and others to long-term goals. For instance, sharing a link to pass the time is different from sharing a link to build one's reputation.

Unsurprisingly, there is no consensus about motivation categories for sharing or forwarding content, and there are tensions between category types. For instance, while Hui-Min Lai and Tsung Teng Chen (2014) include "reputation" as a category, there are several motivations in other typologies that could fit into, if not replace, the reputation category while also overlapping with others, such as "status seeking" (Lee \& Ma, 2012), "distinguishing oneself" (Wong \& Burkell, 2017), "promoting work" (Baek et al., 2011), "personal gain" (Hew \& Hara, 2007), or too "define oneself" (The New York Times Customer Insight Group, 2011).

In another instance, "altruism" (Hew \& Hara, 2007; Oh \& Syn, 2015) presents a broad enough category that it could comprise or overlap with "promoting work" (Baek et al., 2011) or "bring value to/entertain others" (The New York Times Customer Insight Group, 2011. To complicate matters further, ethical egoists would contend that "status 
seeking" (Lee \& Ma, 2012) subsumes the "altruism" category. Indeed, broadly conceived, status seeking could include motivations as diverse as "personal gain" (Hew \& Hara, 2007), "self-fulfillment and connection" (The New York Times Customer Insight Group, 2011), and "affection" (Ho \& Dempsey, 2010).

In order to organize and understand previous research on sharing motivation, this article summarizes the categories found in the literature by broadly grouping each author's motivation categories into three main themes: helping others, helping oneself, and socializing (see Table 1). Four motivations are categorized as "miscellaneous." This summary does not resolve the inherent difficulties in comparing each of the different approaches but it hopefully shows some of the similarities and differences between them that informed the formation of a new motivation typology.

\section{Table 1: Summary of motivations for sharing on social media found in the literature}

\begin{tabular}{|c|c|c|c|c|c|c|c|c|c|}
\hline \multicolumn{2}{|c|}{ Motivation } & \multicolumn{8}{|c|}{ Article describing each motivation } \\
\hline & & $\begin{array}{l}\text { Hew \& } \\
\text { Hara } \\
(2007)\end{array}$ & \begin{tabular}{|l} 
Baek \\
et al. \\
$(2011) /$ \\
Holton \\
et al. \\
$(2014)$
\end{tabular} & $\begin{array}{l}\text { Wong } \\
\& \\
\text { Burkell } \\
(2017)\end{array}$ & $\begin{array}{l}\text { Oh \& } \\
\text { Syn } \\
(2015)\end{array}$ & $\begin{array}{l}\text { NY } \\
\text { Times } \\
(2011)\end{array}$ & $\begin{array}{l}\text { Lee } \\
\& \mathrm{Ma} \\
(2012)\end{array}$ & $\begin{array}{l}\text { Ho \& } \\
\text { Dempsey } \\
(2010)\end{array}$ & $\begin{array}{l}\text { Lai \& } \\
\text { Chen } \\
(2014)\end{array}$ \\
\hline \multirow{5}{*}{$\begin{array}{l}\text { Benefit } \\
\text { others }\end{array}$} & Altruism & $\mathrm{X}$ & & & $\mathrm{X}$ & & & $\mathrm{X}$ & \\
\hline & Entertain & & & $\mathrm{X}$ & & $\mathrm{X}$ & & & \\
\hline & Help others & & & & & & & & $\mathrm{X}$ \\
\hline & Inform others & & $\mathrm{X}$ & $\mathrm{X}$ & & $\mathrm{X}$ & & & \\
\hline & Promotion & & $\mathrm{X}$ & & & & & & \\
\hline \multirow{14}{*}{$\begin{array}{l}\text { Benefit } \\
\text { self }\end{array}$} & Changing minds & & & $\mathrm{X}$ & & & & & \\
\hline & Control & & $\mathrm{X}$ & & & & & $\mathrm{X}$ & \\
\hline & Define oneself & & & & & $\mathrm{X}$ & & & \\
\hline & $\begin{array}{l}\text { Distinguishing } \\
\text { oneself }\end{array}$ & & & $\mathrm{X}$ & & & & $\mathrm{X}$ & \\
\hline & Enjoyment & & & & $\mathrm{X}$ & & & & \\
\hline & Entertainment & & & & & & $\mathrm{X}$ & & \\
\hline & $\begin{array}{l}\text { Knowledge } \\
\text { self-efficacy }\end{array}$ & & & & $\mathrm{X}$ & & & & $\mathrm{X}$ \\
\hline & Learning & & & & $\mathrm{X}$ & & $\mathrm{X}$ & & \\
\hline & Pass time & & $\mathrm{X}$ & & & & & & \\
\hline & $\begin{array}{l}\text { Personal gain } \\
\text { (commercial) }\end{array}$ & $\mathrm{X}$ & & & $\mathrm{X}$ & & & & \\
\hline & Reputation & & & & $\mathrm{X}$ & & & & $\mathrm{X}$ \\
\hline & Self-efficacy & & & & & & & & \\
\hline & Self-fulfillment & & & & & $\mathrm{X}$ & & $\mathrm{X}$ & \\
\hline & Status seeking & & & & & & $\mathrm{X}$ & & \\
\hline
\end{tabular}

Moscrop, David R.H., Wong, Lorraine, \& Alperin, Juan Pablo. (2020). Have You Seen This? Why Political Pundits Share Scholarly Research on Social Media. Scholarly and Research Communication, 11(1): 0101355, $21 \mathrm{pp}$.
Scholarly and Research

\section{Communication}

VOLUME 11 / ISSUE 1 / 2020 
Scholarly and Research

Communication

VOLUME 11 / ISSUE 1 / 2020
Table 1 (continued)

\begin{tabular}{|c|c|c|c|c|c|c|c|c|c|}
\hline \multicolumn{2}{|l|}{ Motivation } & \multicolumn{8}{|c|}{ Article describing each motivation } \\
\hline & & $\begin{array}{l}\text { Hew \& } \\
\text { Hara } \\
(2007)\end{array}$ & $\begin{array}{l}\text { Baek } \\
\text { et al. } \\
(2011) / \\
\text { Holton } \\
\text { et al. } \\
(2014)\end{array}$ & $\begin{array}{l}\text { Wong } \\
\& \\
\text { Burkell } \\
(2017)\end{array}$ & $\begin{array}{l}\text { Oh \& } \\
\text { Syn } \\
(2015)\end{array}$ & $\begin{array}{l}\text { NY } \\
\text { Times } \\
(2011)\end{array}$ & $\begin{array}{l}\text { Lee } \\
\& \mathrm{Ma} \\
(2012)\end{array}$ & $\begin{array}{l}\text { Ho \& } \\
\text { Dempsey } \\
(2010)\end{array}$ & $\begin{array}{l}\text { Lai \& } \\
\text { Chen } \\
(2014)\end{array}$ \\
\hline \multirow{10}{*}{$\begin{array}{l}\text { Social } \\
\text { connection }\end{array}$} & $\begin{array}{l}\text { Being part of a } \\
\text { crowd }\end{array}$ & & & $\mathrm{X}$ & & & & $\mathrm{X}$ & \\
\hline & $\begin{array}{l}\text { Commitment to } \\
\text { group }\end{array}$ & $\mathrm{X}$ & & & & & & & \\
\hline & $\begin{array}{l}\text { Community } \\
\text { interest }\end{array}$ & & & & $\mathrm{X}$ & & & & \\
\hline & Empathy & & & & $\mathrm{X}$ & & & & \\
\hline & $\begin{array}{l}\text { Grow and nour- } \\
\text { ish relationships }\end{array}$ & & & & & $\mathrm{X}$ & & & \\
\hline & $\begin{array}{l}\text { Inclusion (be part } \\
\text { of the group or be } \\
\text { distinct) }\end{array}$ & & & $\mathrm{X}$ & & & & $\mathrm{X}$ & \\
\hline & $\begin{array}{l}\text { Interpersonal } \\
\text { utility }\end{array}$ & & $\mathrm{X}$ & & & & & & \\
\hline & $\begin{array}{l}\text { Maintaining } \\
\text { connection }\end{array}$ & & & $\mathrm{X}$ & & & & & \\
\hline & Reciprocity & $\mathrm{X}$ & & & $\mathrm{X}$ & & & & $\mathrm{X}$ \\
\hline & $\begin{array}{l}\text { Socializing/social } \\
\text { engagement }\end{array}$ & & & & $\mathrm{X}$ & & $\mathrm{X}$ & & \\
\hline \multirow{4}{*}{$\begin{array}{l}\text { Miscellan- } \\
\text { eous }\end{array}$} & Convenience & & $\mathrm{X}$ & & & & & & \\
\hline & $\begin{array}{l}\text { Ease of technol- } \\
\text { ogy use }\end{array}$ & $\mathrm{X}$ & & & & & & & \\
\hline & $\begin{array}{l}\text { Consumption } \\
\text { behaviours }\end{array}$ & & & & & & & $\mathrm{X}$ & \\
\hline & External goals & $\mathrm{X}$ & & & & & & & \\
\hline
\end{tabular}

\section{Methods}

To understand how scholarly information is distributed in the networked public sphere, this study looks at major national pundits in Canada. To do so, tweets were collected and coded, inferring motivation based on a motivation taxonomy distilled and modified from a survey of several similar studies noted above (see Baek et al., 2011; Hew \& Hara, 2007; Ho \& Dempsey, 2010; Lai \& Chen, 2014; Lee \& Ma, 2012; Oh \& Syn, 2015; The New York Times Customer Insight Group, 2011). The tweets were situated by examining them and the context in which they were sent through discourse analysis (Hewis, 2015; Jost, Barberá, Bonneau, Langer, Metzger, Nagler, Sterling, \& Tucker, 2018; Kim, Yang, Abels, \& Zhang, 2012; Langer, Jost, Bonneau, Metzger, Noorbaloochi, \& Penfold-Brown, 2019; Mazarakis \& Peters, 2015).

\section{Pundits}

A list of pundits was chosen based on a set of criteria that would make it possible to investigate the types of motivation that emerged from pundits who are active on Twitter and who write for leading Canadian publications. The intention was not to prepare a comprehensive or random sample but to make sufficient observations to illumi-

Moscrop, David R.H., Wong, Lorraine, \& Alperin, Juan Pablo. (2020). Have You Seen This? Why Political Pundits Share Scholarly Research on Social Media. Scholarly and Research Communication, 11(1): 0101355, $21 \mathrm{pp}$. 
nate a dark corner of social media behaviour by exploring whether pundits are motivated to share scholarly research at all, and to understand what those motivations might be. This study is an initial step toward understanding the nature of the scholarly research shared by pundits, how often they share it, and what motivates them to do so.

To begin, 32 pundits were chosen who met the following criteria:

1. Writes for a widely circulated publication (circulation of at least 500,000) ${ }^{1}$;

2. Writes for a publication that is an English language, national ${ }^{2}$ Canadian publication (or a dedicated Canadian branch of a foreign publication, e.g., Vice Canada);

3. Writes commentary pieces about politics (not necessarily exclusively); and

4. Is an active Twitter user (one or more tweets per day on average) with a significant following (at least 2,00o Twitter followers).

The study focused on English language publications and excluded French language publications because the only language in common for the research team was English and because most research shared on Twitter is is written and tweeted in English (Barata, Shores, \& Alperin, 2018; Haustein, Barata, \& Alperin, 2018). The final list of publications was (in alphabetical order): Buzzfeed Canada, Canadian Broadcasting Corporation, Globe and Mail, iPolitics, Maclean's Magazine, Metro News Canada, National Observer, National Post (and Financial Post), Ottawa Citizen, Toronto Star, and Vice Canada. A Twitter activity threshold of one or more tweets per day (on average across the life of the account at the time) was chosen to ensure that users were likely to be regular to moderately regular users with at least a modest following (for a Canadian public figure). ${ }^{3}$ The follower count is important given that the likelihood that a shared scholarly article is seen and the number of people by whom it is seen is typically dependent on a user's number of followers (Haustein, 2019).

A small number of the pundits also happen to be appointed to academic positions, but writers were not selected based on whether they are a scholar. ${ }^{4}$ Pundits from four digital-only publications (Vice Canada, Buzzfeed Canada, iPolitics, and National Observer) were included as a reflection of the increasingly important role that digital-only publications play in the media landscape. ${ }^{5}$

Using the Twitter usernames of these 32 pundits, all their tweets with links to scholarly publications from the Altmetric database were extracted. Altmetric is a company that specializes in tracking mentions to academic publications from a wide range of sources, including Twitter. The copy of the Altmetric database used in this study contains Twitter mentions made between November 2011 and June 2016. Entries include the content of the tweet (with a link to the tweet online), the title of the article, the name of the publication (typically an academic journal), the publication date of the scholarly piece, and the publication's digital object identifier (DOI).

The resulting group was relatively balanced with regards to gender ( $41 \%$ were women) (see Figure 1a) and the type of publication the pundits primarily wrote for (see Figure 1b). Over half of them wrote for a daily newspaper, one-sixth wrote for magazines, and one-fifth wrote for online-only outlets (the remaining two pundits wrote for various
VOLUME 11 / ISSUE 1 / 2020 
Scholarly and Research

\section{Communication}

VOLUME 11 / ISSUE 1 / 2020

publications). Pundits had a minimum of 2,00o Twitter followers. Around one-third of the pundits (11) had less than 10,00o followers, and two-thirds (21) had less than 20,000 (see Figure 1c). Three (9\%) of the pundits were academics. To better understand each pundit's tweeting behaviour, their Twitter profile page for the date closest to June 2016 was reviewed via the Internet Archive. Collectively, the pundits tweeted an estimated 687,300 times, with an average of 27,500 tweets each $(S D=26,600)$.

\section{Figure 1a: Gender breakdown of pundits}

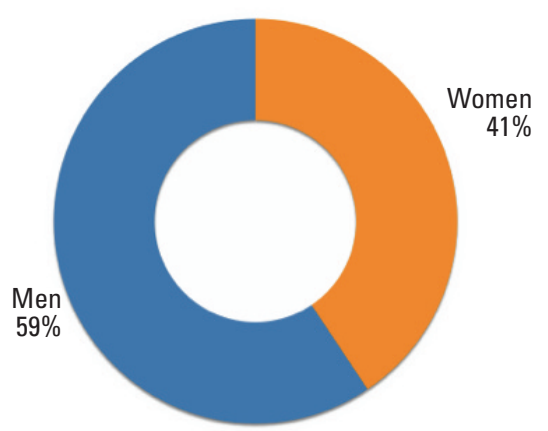

Figure 1b: Publication types pundits primarily write for

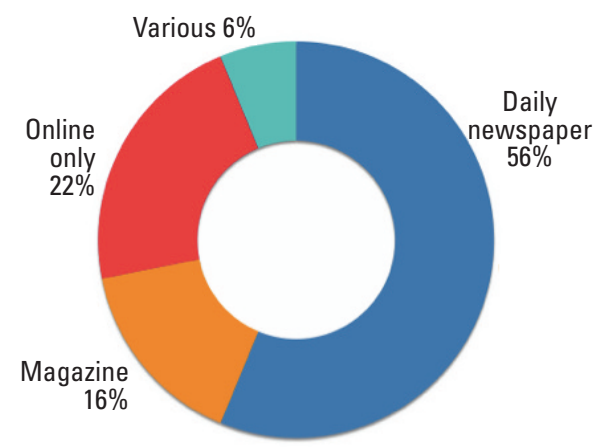

Figure 1c: Number of followers pundits had in August 2017

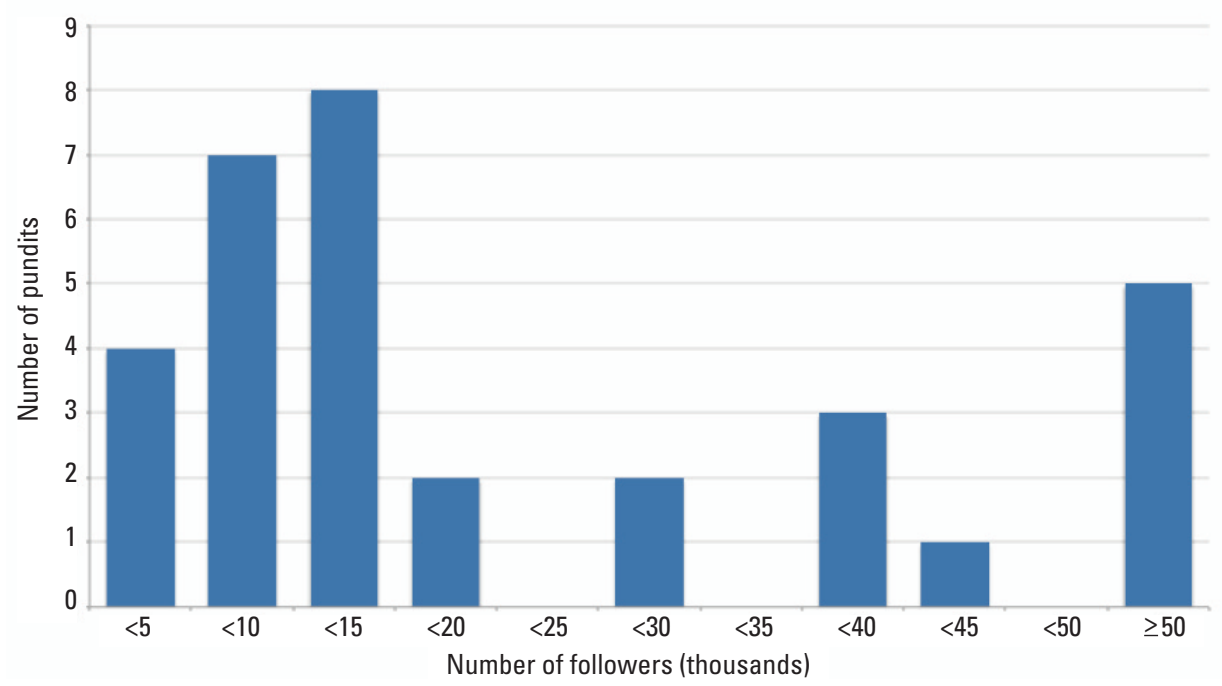

\section{Motivation TYPOLOGY}

Each tweet was classified into an exclusive category of motivation that captures the primary intention of the tweet in which the pundit linked to a scholarly publication. This classification simplifies some of the complex nature of motivations, but it offers an approximation of the central intent of the sharer. While it is likely that pundits sharing research will be motivated by different considerations or goals, some of which may overlap or even compete with one another, the approach to categorize motivations into an exclusive category of primary intention is consistent with the motivation literature discussed above. Primary motivations can often be deduced and can reveal a classifiable intent insofar as the subject displays a recognizable central goal or motivation. This approach is based on ideal-type categories of motivations, which are based on a synthesis of the motivation literature presented. 
The categories of motivation were generated through an inductive approach and checked against motivation typologies of online sharing found in the literature (see

Table 1). The typology builds on the general themes found throughout those typologies, but it is adapted to be parsimonious and fitted to the specific purpose of this study: an examination of the primary motivations of political pundits. Asking what motivates a political pundit to share scholarly research is equivalent to asking: "To what immediate end are they sharing this research?"

Tweets in the sample exhibited a mix of both typically professional and typically personal motivations, which is perhaps unsurprising since pundits are, by definition, expected to share information as part of their work as commentators. Accordingly, it felt less appropriate to make fine-grained distinctions of how the individual benefits themselves or others, and more important to think about the pundits' motivations in their function as someone who has an "imagined audience" (Litt, 2012, p. 1). This approach made it possible to focus on a specific range of motivations in a parsimonious way, avoiding the problem of the overlapping series of motivations, such as status-seeking, altruism, and empathy, that are found in other works on motivations of online sharing. This review of the literature led to behaviour being further categorized into benefits others, benefits oneself, social connection (which falls between benefitting others and benefitting oneself), and miscellaneous (for four outlier types). Four categories were landed on: discussing, promoting, disseminating, and socializing. These reflect a focus on immediate motivations for sharing material in the pundit's capacity as a professional political commentator (even if those immediate motivations serve a long-term commitment, such as interest in a particular political issue), and also as a person with general interests. The categories are described in more detail below.

\section{Debating}

Tweets sharing scholarly research that can be classified as debating were sent primarily as a means to support a point in an argument, to refute the argument of another, or to engage in argumentative or deliberative discussion and debate. These tweets include scholarly research as evidence and thus tend to be a part of a broader conversation, either in the short-term (e.g., as part of an immediate online conversation) or in the long-term (e.g., as part of an individual's ongoing commitment to an issue). For instance, Maclean's pundit Scott Gilmore cited an article from the Journal of Consumer Research to make a point about "slacktivism” and political engagement: “@joshspear Maybe, but as this study proved hashtags make it ${ }^{\star}$ less ${ }^{\star}$ likely you’ll do something useful, like donate. http://t.co/bQhheqS65" (Gilmore, 2015).

\section{Promoting}

Tweets that fall under the "promoting" category primarily involve explicit promotion, including self-promotion. This typically includes tweets in which the primary purpose is linking to one's own scholarly research or the scholarly research of another to alert an audience to its existence, such as this tweet by Emmett Macfarlane about the publication of his article in the Journal of Regional \& Federal Studies: "My latest article (finally in print) with @AlainGGagnon on the politics of representative bureaucracy. http://t.co/kvokCekwFs." Macfarlane (2014). While further commentary may precede or follow promotional tweets (for instance, commenting on the article in more detail),

Moscrop, David R.H., Wong, Lorraine, \& Alperin, Juan Pablo. (2020). Have You Seen This? Why Political Pundits Share Scholarly Research on Social Media. Scholarly and Research Communication, 11(1): 0101355, $21 \mathrm{pp}$.
VOLUME 11 / ISSUE 1 / 2020 
Scholarly and Research Communication

VOLUME 11 / ISSUE 1 / 2020 the primary purpose of the tweet is the promotion of a piece of scholarly research published in an academic journal.

Economist and pundit Stephen Gordon provides another example of promotional motivation for sharing through his retweet of fellow economist Kevin Milligan: "RT @kevinmilligan: Here is my latest in CJE http://t.co/EwZ21Jta I make calx to assess the range for revenue-maxing taxrate in Canada. How high can inctax go" (Gordon, 2011)?

\section{Disseminating}

In the disseminating category, the primary end to sharing scholarly research is the acquisition or sharing of knowledge for a general interest purpose; it is separated from any other immediate end, such as arguing or promoting. This category could also be understood as primarily geared toward general interest, as a pundit draws attention to the research to share some knowledge contained in the research. For instance, National Post columnist Andrew Coyne retweeted a tweet by radio talk show host Rob Breakenridge that cited a study from the Annals of Emergency Medicine, but also displayed a clear interest in ice hockey: “RT @RobBreakenridge: Results of 1,300 Consecutive NHL Fights: Fists of Fury With Minimal Injuries (Annals of Emergency Medicine) http://t.co/uo1IlXuJ." In another example, economist Stephen Gordon took an interest in comparative internal migration rates in Canada and the United States: "Whoa. US internal migration rates are *huge* compared to Canada's: http://t.co/G27V tnClNF" (Gordon, 2013).

\section{Socializing}

In the socializing category, scholarly research is shared on Twitter primarily for entertainment, including mockery, or to forward or respond to scholarly research that has garnered greater-than-usual attention online. The primary purpose is either to be part of a group, to entertain, or to foster belonging rather than to impart knowledge. For instance, in 2014 there was an "editorial oversight" in the journal Ethology (Nature, 2014, n.p.). One of the article's authors forgot to remove an editorial note he had made in parentheses "Should we cite the crappy Gabor paper here?" (Nature, 2014, n.p.). The article quickly became a touchstone on social media known as "The crappy Gabor paper." Globe and Mail pundit Doug Saunders tweeted: “The 'crappy Gabor paper,' it turns out, is about choosing sex partners for physical security rather than reproduction http://t.co/LTvYza7sL8." Toronto Star pundit Heather Mallick shared the research, wondering how the error made it through the editorial process: "Not sure how this made it through proofreading, peer review, and copyediting. Via http://t.co/sWaswaM2X 4 \#addedvalue http://t.co/8krLlvthAr." In a similar vein, Saunders also shared the following: "Peer-reviewed academic journal has a paper titled 'Fuck Jared Diamond.' It makes some good points. http://t.co/WoorARBjEH (via @markKersten)” Saunders (2013).

\section{CoDING}

Using the categories above, two coders (David Moscrop and Lorraine Wong) classified each of the tweets $(N=304)$ independently in a series of coding rounds. The initial round of coding yielded 73.6 percent agreement (224 matches out of 304 tweets). After discussing the disagreements and updating the codebook (see Appendix A), the researchers conducted a second round of coding with the 80 tweets that were not

Moscrop, David R.H., Wong, Lorraine, \& Alperin, Juan Pablo. (2020). Have You Seen This? Why Political Pundits Share Scholarly Research on Social Media. Scholarly and Research Communication, 11(1): 0101355, $21 \mathrm{pp}$. 
agreed on. Though the initial level of agreement was high, discussion indicated that the disagreements were the product of ambiguity in the first iteration of the codebook, which resulted in contextual and referential misunderstandings. More specifically, the codebook was updated to note that "debating" included back-and-forth discussions that could appear to be general interest (e.g., disseminating), that "promoting" included suggestions for readers to review the work of the tweeter or their friends or colleagues, and that an exchange on Twitter could contain different motivations but that the pundit's tweet should be coded on its own characteristics (using the exchange to better understand the context only).

The second round of coding generated a match rate of 51 percent (41 matches out of 80 tweets); the two rounds combined had a match rate of 87 percent (265 matches out of 304 tweets). In the final round, the researchers discussed the remaining tweets and reached agreement on each, one by one. In this discussion, each tweet was examined in detail alongside the codebook and within the context it was sent: when it was sent, by whom, to whom, and whether it was an initial tweet, a reply, or part of a series of tweets. The final round of coding brought the agreement to 100 percent.

\section{Results}

While the quantities and proportions to follow are not necessarily generalizable, since the sample is neither random nor representative, the findings indicate that there are certain tendencies and patterns among top Canadian pundits when it comes to sharing scholarly research on Twitter that may serve as a basis of, or complementary addition to, further study, including network analyses of the circulation of scholarly research by pundits or others.

First, the pundits studied here do tend to share scholarly research online. Of the initial sample of 32 pundits, 25 ( $78 \%)$ tweeted a link to one or more scholarly publication during the sample period. However, although a large majority of them shared research, they did so infrequently. From that period, there were just 304 instances of pundits sharing scholarly research out of the estimated 687,300 total tweets. Of the 25 pundits who tweeted at least one link to an article, almost half (11) did so less than five times and another seven did so less than 10 times (see Figure 2). Except for the three pundits who had sent fewer than 2,500 total tweets (Heather Mallick, Leah McLaren, and Anne Kingston), the tweets linking to research articles made up well below one percent of each pundit's total tweets at the time.
Figure 2: Distribution of the volume of tweets with links to research

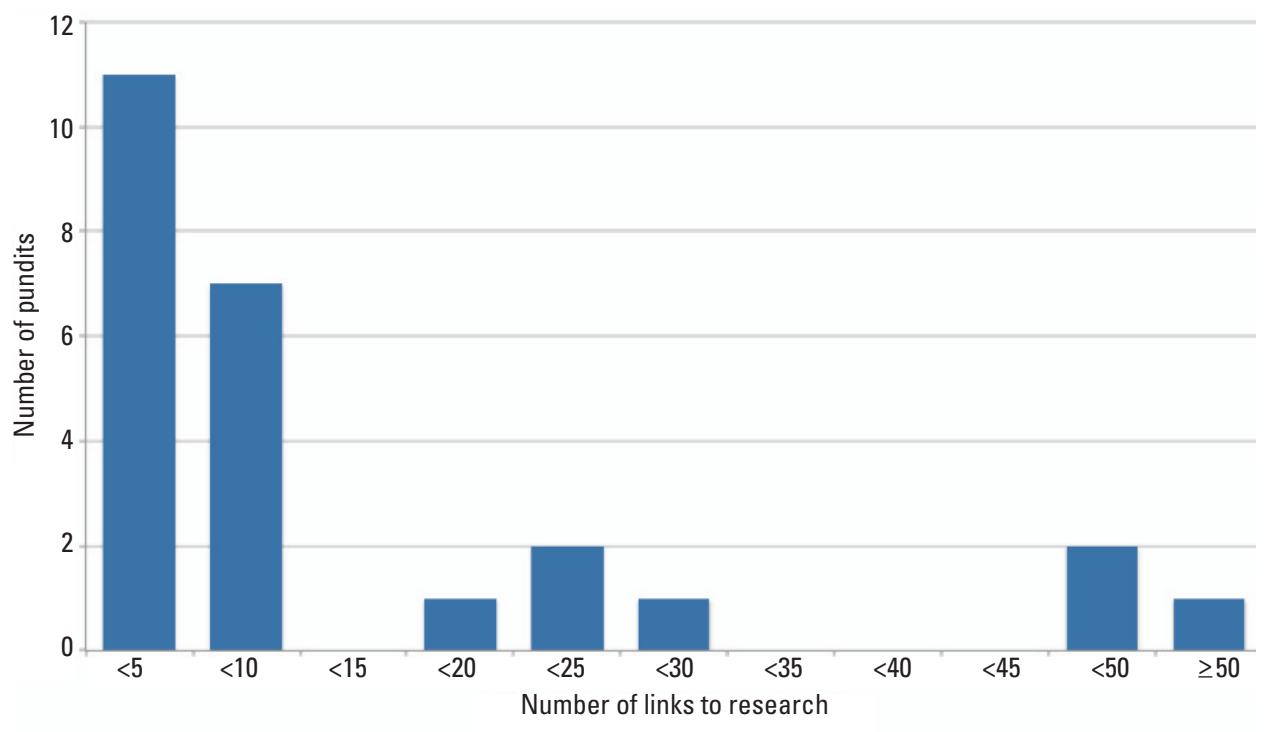


Scholarly and Research

Communication

VOLUME 11 / ISSUE 1 / 2020
Second, when the pundits shared scholarly research online, nearly half of the tweets were motivated by a desire to disseminate scholarly information. This finding suggests that the pundits share a clear general interest motivation for circulating scholarly material compared to other strategic motivations such as promotion, debate, or diversion. Of the 304 tweets sent, 150 (49.3\%) of them were motivated by disseminating, compared to $61(20 \%)$ for promoting, $47(15 \%)$ for socializing, and $46(15 \%)$ for debating (see Table 2).

Table 2: Number and percent of tweets that include links to research by motivation

\begin{tabular}{|l|c|c|c|}
\hline \multirow{2}{*}{ Motivation } & \multicolumn{2}{|c|}{ Total tweets } & \multirow{2}{*}{$\begin{array}{c}\text { Normalized } \\
\text { by pundit }\end{array}$} \\
\cline { 2 - 3 } & Number & Percent & $17 \%$ \\
\hline Debating & 46 & $15 \%$ & $55 \%$ \\
\hline Disseminating & 150 & $49 \%$ & $14 \%$ \\
\hline Promoting & 61 & $20 \%$ & $14 \%$ \\
\hline Socializing & 47 & $15 \%$ & $\mathbf{1 0 0} \%$ \\
\hline Total & $\mathbf{3 0 4}$ & $\mathbf{1 0 0} \%$ & \\
\hline
\end{tabular}

The global counts are affected by individual tendencies, and, since some pundits share more often than others, their motivations skew the results. For instance, Emmett Macfarlane shares the most research (perhaps by virtue of being an academic himself) and does so to promote his work or the work of others 54 percent of the time. Doug Saunders, another prolific tweeter of research, tweets for disseminating 67 percent of the time (see Table 3).

Table 3: Distribution of motivations for tweeting research by each pundit

\begin{tabular}{|l|l|c|c|c|c|c|}
\hline Name & Twitter handle & Debating & $\begin{array}{l}\text { Dissem- } \\
\text { inating }\end{array}$ & $\begin{array}{l}\text { Promot- } \\
\text { ing }\end{array}$ & $\begin{array}{l}\text { Social- } \\
\text { izing }\end{array}$ & $\begin{array}{l}\text { Total } \\
\text { tweets }\end{array}$ \\
\hline Emmett Macfarlane & EmmMacfarlane & $11 \%$ & $26 \%$ & $54 \%$ & $9 \%$ & 65 \\
\hline Stephen Gordon & stephenfgordon & $21 \%$ & $45 \%$ & $15 \%$ & $19 \%$ & 47 \\
\hline Doug Saunders & DougSaunders & $9 \%$ & $67 \%$ & $0 \%$ & $24 \%$ & 45 \\
\hline Andrew Coyne & acoyne & $15 \%$ & $31 \%$ & $27 \%$ & $27 \%$ & 26 \\
\hline Scott Gilmore & Scott_Gilmore & $14 \%$ & $77 \%$ & $9 \%$ & $0 \%$ & 22 \\
\hline Terence Corcoran & terrencecorcoran & $24 \%$ & $57 \%$ & $5 \%$ & $14 \%$ & 21 \\
\hline Sandy Garossino & Garossino & $13 \%$ & $73 \%$ & $7 \%$ & $7 \%$ & 15 \\
\hline Jennifer Robson & JenniferRobson8 & $11 \%$ & $56 \%$ & $33 \%$ & $0 \%$ & 9 \\
\hline Paul Wells & InklessPW & $0 \%$ & $86 \%$ & $14 \%$ & $0 \%$ & 7 \\
\hline Stephen Maher & stphnmaher & $14 \%$ & $57 \%$ & $14 \%$ & $14 \%$ & 7 \\
\hline Drew Brown & drewfoundland & $50 \%$ & $17 \%$ & $17 \%$ & $17 \%$ & 6 \\
\hline Anne Kingston & anne_kingston & $0 \%$ & $100 \%$ & $0 \%$ & $0 \%$ & 5 \\
\hline Heather Mallick & HeatherMallick & $0 \%$ & $80 \%$ & $0 \%$ & $20 \%$ & 5 \\
\hline Tabatha Southey & TabathaSouthey & $20 \%$ & $0 \%$ & $0 \%$ & $80 \%$ & 5 \\
\hline Chris Selley & cselley & $50 \%$ & $0 \%$ & $0 \%$ & $50 \%$ & 4 \\
\hline Susan Delacourt & SusanDelacourt & $0 \%$ & $100 \%$ & $0 \%$ & $0 \%$ & 3 \\
\hline
\end{tabular}

Moscrop, David R.H., Wong, Lorraine, \& Alperin, Juan Pablo. (2020). Have You Seen This? Why Political Pundits Share Scholarly Research on Social Media. Scholarly and Research Communication, 11(1): 0101355, $21 \mathrm{pp}$. 
Table 3 (continued)

\begin{tabular}{|l|l|r|r|r|r|c|}
\hline Name & Twitter handle & Debating & $\begin{array}{l}\text { Dissem- } \\
\text { inating }\end{array}$ & $\begin{array}{l}\text { Promot- } \\
\text { ing }\end{array}$ & $\begin{array}{l}\text { Social- } \\
\text { izing }\end{array}$ & $\begin{array}{l}\text { Total } \\
\text { tweets }\end{array}$ \\
\hline Barbara Kay & BarbaraRKay & $0 \%$ & $50 \%$ & $0 \%$ & $50 \%$ & 2 \\
\hline Jen Gerson & jengerson & $50 \%$ & $50 \%$ & $0 \%$ & $0 \%$ & 2 \\
\hline Terry Glavin & TerryGlavin & $50 \%$ & $0 \%$ & $50 \%$ & $0 \%$ & 2 \\
\hline Chantale Hebert & ChantalHbert & $0 \%$ & $100 \%$ & $0 \%$ & $0 \%$ & 1 \\
\hline Gary Mason & garymasonglobe & $0 \%$ & $100 \%$ & $0 \%$ & $0 \%$ & 1 \\
\hline John Ivison & IvisonJ & $100 \%$ & $0 \%$ & $0 \%$ & $0 \%$ & 1 \\
\hline John Ibbitson & JohnIbbitson & $0 \%$ & $0 \%$ & $100 \%$ & $0 \%$ & 1 \\
\hline Leah McLaren & leahmclaren & $0 \%$ & $100 \%$ & $0 \%$ & $0 \%$ & 1 \\
\hline Vicky Mochama & vmochama & $0 \%$ & $100 \%$ & $0 \%$ & $0 \%$ & 1 \\
\hline
\end{tabular}

This points to a third finding: some pundits tend to take on a "sharing type" (see Table 3). Of the 14 pundits who tweeted at least five articles, six were motivated to circulate scholarly research by a desire to learn and teach at least two-thirds of the time; another three had this motivation at least half the time. Other pundits were much more balanced in their motivations, such as Andrew Coyne. Eleven of the pundits were infrequent sharers, regardless of their primary category of motivation, sharing scholarly material fewer than five times in the five-year period covered by this study.

This study corrects for these trends by normalizing each pundit's motivations as a percentage of all their tweets in the dataset and then taking the average of these to determine the global average by type. Making this adjustment increases the average percentage of tweets that are for disseminating to 55 percent (up from $49 \%$ when simply counting) and decreases the percent of tweets for the purpose of promoting to 14 percent (down from $20 \%$ when simply counting). The percentages for the other two motivations also vary slightly (see Table 2).

To further understand these sharing types, this study explored whether pundits were introducing articles into the networked public sphere or sharing articles that were already widely circulated by using two additional metrics: the number of times the pundit was the first person to tweet the article and the median number of days that elapsed since the article first appeared on Twitter. There was a wide range of behaviours (see Table 4). Some pundits (13), especially those who did not tweet research articles often, were never the first to share the research on Twitter. Other pundits (4) gravitated toward never-before-shared articles as much as one out of every three times they tweeted research. Naturally, pundits that had a propensity to share new articles exhibited low median times to tweet (having a zero time for all the articles for which they were first). However, they are not the only ones to share articles shortly after they are first introduced on Twitter. Of the 25 pundits who shared research, 15 (60\%) have a median time to tweet of less than one day, and an additional four (16\%) of less than a week. That is, the majority of pundits $(76 \%)$ are either the first to share an article or share it within the first few days of their appearance on Twitter. Understanding how pundits discovered the research was beyond the scope of this study, but would be valu-

Moscrop, David R.H., Wong, Lorraine, \& Alperin, Juan Pablo. (2020). Have You Seen This? Why Political Pundits Share Scholarly Research on Social Media. Scholarly and Research Communication, 11(1): 0101355, $21 \mathrm{pp}$.
VOLUME 11 / ISSUE 1 / 2020 
Scholarly and Research

Communication

VOLUME 11 / ISSUE 1 / 2020 able in understand both their motivations and the process of dissemination from first contact to their eventual sharing on Twitter.

Table 4: Time from first appearance of research and its popularity on Twitter by pundit

\begin{tabular}{|c|c|c|c|c|c|c|}
\hline Name & Username & $\begin{array}{c}\text { Number } \\
\text { of } \\
\text { tweets }\end{array}$ & $\begin{array}{l}\text { Number } \\
\text { of first } \\
\text { to tweet }\end{array}$ & $\begin{array}{l}\text { Percent } \\
\text { of first } \\
\text { to tweet }\end{array}$ & $\begin{array}{l}\text { Median } \\
\text { time to } \\
\text { tweet }\end{array}$ & $\begin{array}{l}\text { Median } \\
\text { number } \\
\text { of tweets }\end{array}$ \\
\hline Emmett Macfarlane & EmmMacfarlane & 65 & 11 & $17 \%$ & 0.9 & 23.5 \\
\hline Stephen Gordon & stephenfgordon & 47 & 17 & $36 \%$ & 0.0 & 10 \\
\hline Doug Saunders & DougSaunders & 45 & 16 & $36 \%$ & 0.5 & 21 \\
\hline Andrew Coyne & acoyne & 26 & 2 & $8 \%$ & 0.6 & 54 \\
\hline Scott Gilmore & Scott_Gilmore & 22 & 2 & $9 \%$ & 39.4 & 99.5 \\
\hline Terence Corcoran & terrencecorcoran & 21 & 1 & $5 \%$ & 6.0 & 73 \\
\hline Sandy Garossino & Garossino & 15 & 2 & $13 \%$ & 15.9 & 116 \\
\hline Jennifer Robson & JenniferRobson8 & 9 & 2 & $22 \%$ & 0.0 & 7 \\
\hline Paul Wells & InklessPW & 7 & 2 & $29 \%$ & 0.1 & 258.5 \\
\hline Stephen Maher & stphnmaher & 7 & 1 & $14 \%$ & 1.9 & 360 \\
\hline Drew Brown & drewfoundland & 6 & o & O\% & 60.3 & 11.5 \\
\hline Anne Kingston & anne_kingston & 5 & 0 & $0 \%$ & 3.8 & 74 \\
\hline Heather Mallick & HeatherMallick & 5 & o & O\% & 2.2 & 161 \\
\hline Tabatha Southey & TabathaSouthey & 5 & o & O\% & 0.2 & 39 \\
\hline Chris Selley & cselley & 4 & 1 & $25 \%$ & 0.1 & 38 \\
\hline Susan Delacourt & SusanDelacourt & 3 & 1 & $33 \%$ & 0.7 & 28.5 \\
\hline Barbara Kay & BarbaraRKay & 2 & 0 & $0 \%$ & 905.8 & 523.5 \\
\hline Jen Gerson & jengerson & 2 & o & $\mathrm{O} \%$ & 164.7 & 36 \\
\hline Terry Glavin & TerryGlavin & 2 & o & O\% & 35.9 & 37 \\
\hline Chantale Hebert & ChantalHbert & 1 & o & $0 \%$ & 0.2 & 360 \\
\hline Gary Mason & garymasonglobe & 1 & 0 & o\% & 0.0 & 20 \\
\hline John Ivison & IvisonJ & 1 & 0 & $\mathrm{O} \%$ & 0.9 & 67 \\
\hline John Ibbitson & JohnIbbitson & 1 & 0 & $0 \%$ & 0.2 & 23 \\
\hline Leah McLaren & leahmclaren & 1 & 0 & O\% & 0.0 & 1,481 \\
\hline Vicky Mochama & vmochama & 1 & 0 & O\% & 0.5 & 986 \\
\hline Overall & & 304 & 58 & $19 \%$ & 1.0 & 39 \\
\hline
\end{tabular}

Finally, the study tested whether different sorts of tweets tend to be used for different sorts of online sharing (i.e., are motivated by different ends). The Twitter platform has different affordances for three types of tweets: tweets, retweets, and replies. In this study, a tweet is an original post by a pundit (containing a link to a scholarly article). A retweet re-shares another's tweet (containing a link to a scholarly article) without any changes or additions to the original tweet. ${ }^{6}$ In this dataset, these are preceded by the characters "RT." Finally, a reply is an original tweet (with a link to a scholarly article) 
that responds to someone else's tweet (regardless of whether that tweet included a link to a scholarly article). These tweets always begin with the "@” symbol, followed by a Twitter username.

Using the same normalization approach, large differences were found in the motivations behind each tweet type (see Table 5). Original tweets were primarily used for disseminating ( $63 \%$ of the time). They were used for socializing 18 percent of the time, debating 11 percent, and for promoting just eight percent of the time. This indicates that a majority of the pundits who tweeted scholarly material were doing so out of general interest, perhaps unprompted by others. Similarly, 46 percent of retweets were instances of disseminating. The decrease in the percentage of tweets in this category comes from an increase in retweets or tweets that were done for the purposes of promoting, which is perhaps unsurprising given that retweets are, by their very nature, intended to assist in promoting the contributions of others. In contrast, tweets in which the original motivation was debating were not frequently retweeted, and thus made up a mere 10 percent of retweets. Unsurprisingly, replies were made up of 77 percent instances of debating - pundits were engaging in debates and sharing scholarly material to support their argument. In the reply category, disseminating accounts for just 15 percent of shares.

\section{Table 5: Normalized distribution of motivation across different tweet types}

\begin{tabular}{|l|r|c|c|}
\hline \multirow{2}{*}{ Motivation } & \multicolumn{3}{|c|}{ Tweet type } \\
\cline { 2 - 4 } & Tweet & Retweet & Reply \\
\hline Debating & $11 \%$ & $10 \%$ & $77 \%$ \\
\hline Disseminating & $63 \%$ & $47 \%$ & $14 \%$ \\
\hline Promoting & $8 \%$ & $27 \%$ & $5 \%$ \\
\hline Socializing & $18 \%$ & $17 \%$ & $4 \%$ \\
\hline Total & $\mathbf{1 0 0} \%$ & $\mathbf{1 0 0} \%$ & $\mathbf{1 0 0} \%$ \\
\hline
\end{tabular}

\section{Discussion}

Social media platforms are a key space in which individuals access and share information. This sphere, however, is fraught with risks and challenges, including the massive rise of misinformation and disinformation (including "fake news"), which is common and influential (Vosoughi, Roy, \& Aral, 2018). A productive and inclusive public sphere must be a space for, among other things, self-determination, preference formation, deliberation, and communication (Habermas, 1984, 1989), but these needs require an open flow of reliable information. Peer-reviewed research is a potential counterweight to misinformation, disinformation, or poor information generally. When shared by popular and/or trusted sources, including pundits its effect may be particularly significant. But to have any effect on the public sphere, networked or otherwise, scholarly information must first be circulated.

The study's findings suggest first and foremost that the pundits do indeed share scholarly research, although the majority of them do not do it often. There is a great deal of variability in each pundit's use of scholarly research, although some clear trends emerge. For example, when pundits share research, they do so in a rational way based on their

Moscrop, David R.H., Wong, Lorraine, \& Alperin, Juan Pablo. (2020). Have You Seen This? Why Political Pundits Share Scholarly Research on Social Media. Scholarly and Research Communication, 11(1): 0101355, $21 \mathrm{pp}$. 


\section{Scholarly and Research}

\section{Communication}

VOLUME 11 / ISSUE 1 / 2020 motivations. If they are generally interested in a scholarly article, they will share it in a tweet. If another has shared an article they find interesting, they will retweet (and thus re-share) it. If they are engaged in a debate, they will use scholarly research as evidence in their replies in a thread. Promotion - of themselves or someone else - typically occurs most often by retweet, as does socializing. While the findings suggest possible patterns of motivation and information flow, given the limited sample size and the infrequency of sharing, they fall short of demonstrating a norm or common practice. However, one pattern stands out that is consistent with related literature: 76 percent of pundits who share scholarly research do so within the first week that it appears online, a pattern observed in the broader population of those who tweet research (Haustein, 2019; Haustein et al., 2018). Further research is necessary to confirm whether any of these patterns are generalizable and whether any widespread sharing norms exist.

Perhaps most importantly, and despite the absence of clear evidence of a norm or common practice, these study results show that when a pundit in the sample is motivated to share scholarly research online, they do so to disseminate information, to simply put it into the public sphere; they seek out or encounter scholarly research and use it to inform their own opinions and then act as conduits of information into the public sphere. Indeed, 19 percent of tweets were the first instances of the linked scholarly article being shared on Twitter; in the case of three pundits, one in three of the articles they shared was material that had not been circulated on the site before. These examples of how pundits introduce research into the public sphere highlights the special role they play, even when academic articles are broadly shared by a wide range of individuals and organizations (Haustein et al., 2016; Vainio \& Holmberg, 2017). Additional research that considers where pundits fit within a network of social media users could build on the work of Juan Pablo Alperin, Charles J. Gomez, and Stefanie Haustein (2018), who considered the network characteristics of follower/following relationships to understand how academic articles diffuse on Twitter.

This study also revealed that pundits who shared scholarly material tended to act as knowledge relays, disseminating academic research to thousands of social media users, many of whom seek news and information online (Hermida et al., 2012; Olmstead et al., 2011). Less commonly, and in roughly equal measure, pundits used scholarly material for a different end: to promote themselves or one another, to socialize, or to debate. Whatever their motivation for sharing, however, pundits who circulated scholarly research on Twitter contributed to informing the public of at least the existence and perhaps the content of research that tends to circulate within the closed community of academia. These receiving individuals might reasonably be expected to factor this scholarly research into their thinking about this or that issue or phenomenon.

The media, including pundits, is a key source of information for learning about and forming perceptions of the world (Hanitzsch \& Vos, 2016; Shehata \& Strömbäck, 2014). The findings suggest that insofar as they act as conduits - infrequent as that may be pundits inject scholarly research into that process. As noted, a vibrant and productive public sphere, online and offline, requires that citizens have access to sufficient information that they can use as evidence when forming reasons for and against arguments or preferences. This requires that those individuals have access to materials, including

Moscrop, David R.H., Wong, Lorraine, \& Alperin, Juan Pablo. (2020). Have You Seen This? Why Political Pundits Share Scholarly Research on Social Media. Scholarly and Research Communication, 11(1): 0101355, $21 \mathrm{pp}$. 
scholarly research. Insofar as pundits - who tend to attract well-above-average audiences and followers - act as relays for this research, they play an important, if occasional, part in educating citizens, whatever their original reason for sharing this material.

Even in the networked public sphere, experts and the media are still relied on to respectively produce and disseminate scholarly material to help the public reach informed and considered political judgements. Dissemination has become easier than ever as sharing has become faster, easier, and less expensive. Accordingly, it was not surprising, though it was encouraging, to find that pundits shared scholarly research, even if only infrequently. Given the predominance of unreliable and false information in the networked public sphere, the public would be well served by pundits - and others - sharing scholarly research online more frequently.

Notwithstanding any of these conclusions, and perhaps because of them, the data raises questions about the degree to which access to scholarly materials mediates the likelihood that such material will be shared. Future research building on the work of Kim Holmberg, Juha Hedman, Timothy Berman, Fereshteh Didegah, and Michael Laasko (2020) can help illuminate the effect of access, whether access to material is open or closed, on the likelihood of it being shared on social media. This would help scholars further understand the role that gated and ungated journals play in civic discourse, as would a closer study of what individuals do with shared material. For instance, this study did not include an assessment of whether shared materials were downloaded, bookmarked, printed, read, or otherwise processed by users. Finally, a more general study of the typology of pundits and other types of scholarly material sharers across platforms would further help illuminate how, why, and by whom scholarly research is circulated on social media.

\section{Notes}

1. For reference, the average combined print and digital circulation for Canadian newspapers in 2014 (around the time the sample data was produced) was 305,436 per week (2014 Daily Newspaper Circulation, 2015).

2. The Ottawa Citizen and the Toronto Star were included as national publications. Each has an online presence with a national reach and each pursues significant national politics coverage, the former publishing from Canada's capital city and the latter from Canada's most populous city. According to 2014 data, the Ottawa Citizen posted a circulation of 626,000 weekly papers - print and digital - while the Toronto Star was Canada's most-circulated newspaper with a reach of 2.4 million per week (2014 Daily Newspaper Circulation, 2015).

3. As a rough point of reference, in 2018, according to the Pew Research Center, the median number of followers for a U.S. adult Twitter user in the top ten percent of tweeters was 387 (Wojcik \& Hughes, 2019); in 2016, according to Brandwatch, the global average follower count was 208; it is now 707 (Smith, 2016, 2019).

4. One of the authors of this article, David Moscrop, fits the criteria for inclusion in this study; nonetheless, he was omitted from the review.

5. Digital-only publications were exempt from the circulation criterion but not from any other. In the case of Metro News, the outlet has local publications in five

Moscrop, David R.H., Wong, Lorraine, \& Alperin, Juan Pablo. (2020). Have You Seen This? Why Political Pundits Share Scholarly Research on Social Media. Scholarly and Research Communication, 11(1): 0101355, $21 \mathrm{pp}$.
VOLUME 11 / ISSUE 1 / 2020 


\section{Scholarly and Research}

\section{Communication}

VOLUME 11 / ISSUE 1 / 2020
Canadian cities - Vancouver, Calgary, Edmonton, Halifax, and Toronto - and covers both local, provincial, and national news; it is, effectively, a national publication

6. Twitter users can retweet themselves by retweeting a past tweet. Many do.

\section{Publications}

Buzzfeed Canada, https://www.buzzfeed.com/tag/canada

Canadian Broadcasting Corporation, https://www.cbc.ca/

Globe and Mail, https://www.theglobeandmail.com/

iPolitics, https://ipolitics.ca/

Maclean's Magazine, https://www.macleans.ca/

Metro News Canada, https://www.readmetro.com/en/canada/

National Observer, https://www.nationalobserver.com/

National Post (and the Financial Post), https://nationalpost.com/

Ottawa Citizen, https://ottawacitizen.com/

Toronto Star, https://www.thestar.com/

Vice Canada, https://www.vice.com/en_ca

\section{Websites}

Altmetric, https://www.altmetric.com/

Internet Archive, https://archive.org/

\section{References}

2014 Daily Newspaper Circulation. (2015). News media Canada. URL: http://www.newspaperscanada .ca/sites/default/files/2014\%20Daily\%2oNewspapers\%2oCirculation\%2oby\%2oTitle\%20 SPREADSHEET.xlsx [15/08/2017].

Alperin, J.P., Gomez, C.J., \& Haustein, S. (2018). Identifying diffusion patterns of research articles on Twitter: A case study of online engagement with open access articles. Public Understanding of Science, 28(1), 2-18. doi: 10/gdg6vs

Baek, K., Holton, A., Harp, D., \& Yaschur, C. (2011). The links that bind: Uncovering novel motivations for linking on Facebook. Computers in Human Behavior, 27(6), 2243-2248.

Barata, G., Shores, K., \& Alperin, J.P. (2018). Local chatter or international buzz? Language differences on posts about Zika research on Twitter and Facebook. PLOS ONE, 13(1), e0190482. doi: 1o/gcssvk

Boulianne, S. (2009). Does internet use affect engagement? A meta-analysis of research. Political Communication, 26(2), 193-211.

Chen, G.M. (2011). Tweet this: A uses and gratifications perspective on how active Twitter use gratifies a need to connect with others. Computers in Human Behavior, 27(2), 755-762.

Chiu, C.-M., Hsu, M.-H., \& Wang, E.T. (2006). Understanding knowledge sharing in virtual communities: An integration of social capital and social cognitive theories. Decision Support Systems, $42(3), 1872-1888$.

Coyne, Andrew. (2011).RT @RobBreakenridge: Results of 1,300 Consecutive NHL Fights: Fists of Fury With Minimal Injuries (Annals of Emergency Medicine) http://t.co/uo1IIXuJ [Tweet]. URL: http://twitter.com/\#!/acoyne/status/125702359925010432

Dahlberg, L. (2001). The internet and democratic discourse: Exploring the prospects of online deliberative forums extending the public sphere. Information, Communication \& Society, 4(4), 615-633.

Dahlgren, P. (2005). The internet, public spheres, and political communication: Dispersion and deliberation. Political Communication, 22(2), 147-162.

Moscrop, David R.H., Wong, Lorraine, \& Alperin, Juan Pablo. (2020). Have You Seen This? Why Political Pundits Share Scholarly Research on Social Media. Scholarly and Research Communication, 11(1): 0101355, $21 \mathrm{pp.}$ 
Dahlgren, P. (2013). The political web: Media, participation and alternative democracy. Basingstoke, UK: Palgrave Macmillan.

Elliot, A.J., \& Covington, M.V. (2001). Approach and avoidance motivation. Educational Psychology Review, 13(2), 73-92.

Fung, A. (2013). The principle of affected interests: An interpretation and defense. In J.H. Nagel \& R.M. Smith (Eds.), Representation: Elections and beyond (pp. 236-268). Philadelphia, PA: University of Pennsylvania Press.

Gilmore, Scott. (2015).@joshspear Maybe, but as this study proved hashtags make it *less ${ }^{\star}$ likely you'll do something useful, like donate. http://t.co/bQhheqS65 [Tweet]. URL: https://twitter.com/Scott _Gilmore/status/553930351568240640

Gordon, Stephen. (2011).RT @ kevinmilligan: Here is my latest in CJE http://t.co/EwZ21Jta I make calx to assess the range for revenue-maxing taxrate in Canada. How high can inctax go? [Tweet]. URL: http://twitter.com/\#!/stephenfgordon/status/137879029373083649

Gordon, Stephen. (2013). Whoa. US internal migration rates are ${ }^{\star}$ huge ${ }^{\star}$ compared to Canada's: http:// t.co/G27VtnClNF [Tweet]. URL: http://twitter.com/\#!/stephenfgordon/status/335056717211639808

Habermas, Jürgen. (1984). The theory of communicative action (Vol. 2). Boston, MA: Beacon Press.

Habermas, Jürgen. (1989). The structural transformation of the public sphere (Thomas Burger, Trans.). Cambridge, MA: MIT Press.

Habermas, Jurgen. (1996). Between facts and norms: Contributions to a discourse theory of law and democracy. Cambridge, MA: MIT Press.

Hanitzsch, T., \& Vos, T.P. (2016). Journalism beyond democracy: A new look into journalistic roles in political and everyday life. Journalism, 19(2), 146-164. doi: 10.1177/1464884916673386

Hara, N., \& Foon Hew, K. (2007). Knowledge-sharing in an online community of health-care professionals. Information Technology \& People, 20(3), 235-261.

Haustein S. (2019) Scholarly Twitter metrics. In W. Glänzel, H.F Moed, U. Schmoch, \& M. Thelwall (Eds.), Springer handbook of science and technology indicators. New York, NY: Springer Handbooks. Haustein, S., Barata, G., \& Alperin, J.P. (2018, June 21). It ain’t where you're from, it's where you're tweeting (Or: Where tweets about scholarly articles come from). Altmetric. URL: https://www.altmetric.com/blog/it-aint-where-youre-from-its-where-youre-tweeting-or-where -tweets-about-scholarly-articles-come-from/ [04/08/2019].

Haustein, S., Bowman, T.D., \& Costas, R. (2016). Interpreting "altmetrics": Viewing acts on social media through the lens of citation and social theories. In C.R. Sugimoto (Ed.), Theories of Informetrics (pp. 372-405). Berlin, DE: De Grutyer Mouton. URL: https://arxiv.org/abs/1502 .05701v1 [April 8, 2019].

Haustein, S., \& Costas, R. (2015, November 7). Identifying Twitter audiences: Who is tweeting about scientific papers? URL: https://pdfs.semanticscholar.org/d3eo/c3c2838c50e88887238736765804 d59c362b.pdf [April 8, 2019].

Hermida, A., Fletcher, F., Korell, D., \& Logan, D. (2012). Share, like, recommend: Decoding the social media news consumer. Journalism Studies, 13(5-6), 815-824.

Hew, K.F., \& Hara, N. (2007). Knowledge sharing in online environments: A qualitative case study. Journal of the Association for Information Science and Technology, 58(14), 2310-2324.

Hewis, J. (2015). Do MRI patients tweet? Thematic analysis of patient tweets about their MRI experience. Journal of Medical Imaging and Radiation Sciences, 46(4), 396-402. doi: 10.1016/j.jmir.2015 $.08 .003[08 / 15 / 2017]$.

Ho, J.Y., \& Dempsey, M. (2010). Viral marketing: Motivations to forward online content. Journal of Business Research, 63(9-10), 1000-1006.

Moscrop, David R.H., Wong, Lorraine, \& Alperin, Juan Pablo. (2020). Have You Seen This? Why Political Pundits Share Scholarly Research on Social Media. Scholarly and Research Communication, 11(1): 0101355, $21 \mathrm{pp}$.
Scholarly and Research

\section{Communication}

VOLUME 11 / ISSUE 1 / 2020 


\section{Scholarly and Research Communication}

VOLUME 11 / ISSUE 1 / 2020
Holmberg, K., Hedman, J., Bowman, T.D., Didegah, F., \& Laakso, M. (2020). Do articles in open access journals have more frequent altmetric activity than articles in subscription-based journals? An investigation of the research output of Finnish universities. Scientometrics, 122(1), 645-659. doi: 10.1007/s11192-019-03301-x

Holton, A.E., Baek, K., Coddington, M., \& Yaschur, C. (2014). Seeking and sharing: Motivations for linking on Twitter. Communication Research Reports, 31(1), 33-40.

Jacobs, R.N., \& Townsley, E. (2011). The space of opinion: Media intellectuals and the public sphere. Oxford, UK: Oxford University Press.

Jost, J.T., Barberá, P., Bonneau, R., Langer, M., Metzger, M., Nagler, J., Sterling, J., \& Tucker, J. A. (2018). How social media facilitates political protest: Information, motivation, and social networks. Political Psychology, 39(S1), 85-118. doi: 10.1111/pops.12478

Kim, H.M., Yang, C.C., Abels, E.G., \& Zhang, M. (2012). A qualitative analysis of information dissemination through Twitter in a digital library. Proceedings of the 12th ACM/IEEE-CS Joint Conference on Digital Libraries, 339-340. doi: 10.1145/2232817.2232880

Lai, H.-M., \& Chen, T.T. (2014). Knowledge sharing in interest online communities: A comparison of posters and lurkers. Computers in Human Behavior, 35 (supplement), 295-306.

Langer, M., Jost, J.T., Bonneau, R., Metzger, M.M., Noorbaloochi, S., \& Penfold-Brown, D. (2019). Digital dissent: An analysis of the motivational contents of tweets from an Occupy Wall Street demonstration. Motivation Science, 5(1), 14-34. doi: 10.1037/motooooo84

Lee, C.S., \& Ma, L. (2012). News sharing in social media: The effect of gratifications and prior experience. Computers in Human Behavior, 28(2), 331-339.

Lin, H.-F. (2006). Understanding behavioral intention to participate in virtual communities. CyberPsychology \& Behavior, 9(5), 540-547.

Lin, K.-Y., \& Lu, H.-P. (2011). Why people use social networking sites: An empirical study integrating network externalities and motivation theory. Computers in Human Behavior, 27(3), 1152-1161.

Litt, Eden. (2012). Knock, knock. Who's there? The imagined audience. Journal of Broadcasting \& Electronic Media, 56(3), 330-345.

Mazarakis, A., \& Peters, I. (2015). Science 2.0 and conference tweets: What? Where? Why? When? Electronic Journal of Knowledge Management, 13(4), 269-282.

Macfarlane, Emmett. (2013). My latest article (finally in print) with @AlainGGagnon on the politics of representative bureaucracy. http://t.co/kvokCekwFs [Tweet]. URL: http://twitter.com /EmmMacfarlane/status/397022917688819712.

Mallick, Heather. (2014). Not sure how this made it through proofreading, peer review, and copyediting. Via http://t.co/sWaswaM2X4 \#addedvalue http://t.co/8krLlvthAr [Tweet] URL: https://twitter.com/HeatherMallick/status/532360451662041090 .

Melzer, A.M., Weinberger, J., \& Zinman, M.R. (2003). The public intellectual: Between philosophy and politics. Lanham, MD: Rowman \& Littlefield.

Oh, S., \& Syn, S.Y. (2015). Motivations for sharing information and social support in social media: A comparative analysis of Facebook, Twitter, Delicious, YouTube, and Flickr. Journal of the Association for Information Science and Technology, 66(10), 2045-2060.

Olmstead, K., Mitchell, A., \& Rosenstiel, T. (2011, May 9). Navigating news online. Pew Research Center's Journalism Project. URL: http://www.journalism.org/2011/05/o9/navigating-news -online/ [August 15, 2017].

Oxford English Dictionary Online. (2017). Pundit. URL: https://en.oxforddictionaries.com /definition/pundit [August 15, 2017].

Papacharissi, Z. (2012). Without you, I'm nothing: Performances of the self on Twitter. International Journal of Communication, 6, 1989-2006.

Moscrop, David R.H., Wong, Lorraine, \& Alperin, Juan Pablo. (2020). Have You Seen This? Why Political Pundits Share Scholarly Research on Social Media. Scholarly and Research Communication, 11(1): 0101355, $21 \mathrm{pp}$. 
Posner, R. (2001). Public intellectuals: A study of decline. Cambridge, MA: Harvard University Press. URL: https://chicagounbound.uchicago.edu/books/189/ [05/01/2017].

Priem, J., Taraborelli, D., Groth, P., \& Neylon, C. (2010). Altmetrics: A manifesto. URL: http:// altmetrics.org/manifesto/ [June 17, 2017].

Purcell, K., Rainie, L., Mitchell, A., Rosenstiel, T., \& Olmstead, K. (2010, March 1). Understanding the participatory news consumer. Pew Research Center: Internet \& Technology. URL: http://www .pewinternet.org/2010/03/01/understanding-the-participatory-news-consumer/ [June 17, 2017].

Saunders, Doug. (2014). The 'crappy Gabor paper', it turns out, is about choosing sex partners for physical security rather than reproduction http://t.co/LTvYza7sL8 [Tweet]. URL: https://twitter .com/DougSaunders/status/532537046175600640

Saunders, Doug. (2013). Peer-reviewed academic journal has a paper titled 'Fuck Jared Diamond.' It makes some good points. http://t.co/WoorARBjEH (via @markKersten) [Tweet]. URL: http:// twitter.com/DougSaunders/status/393801650508275712

Schäfer, M.S. (2015). Digital public sphere. The International Encyclopedia of Political Communication. Hoboken, NJ: John Wiley \& Sons, Inc. doi: 10.1002/9781118541555.wbiepco87

Schudson, M. (1998). The good citizen: A history of American civic life. New York, NY: Free Press.

Shehata, A., \& Strömbäck, J. (2014). Mediation of political realities: Media as crucial sources of information. In F. Esser \& J. Strömbäck (Eds.), Mediatization of politics: Understanding the transformation of Western democracies (pp. 93-113). London, UK: Palgrave Macmillan UK. doi: 10.1057 /9781137275844_6

Smith, A., \& Rainie, L. (2010, December 9). 8\% of online Americans use Twitter. Pew Research Center: Internet \& Technology. URL: http://www.pewinternet.org/2010/12/og/8-of-online-americans -use-twitter/ [06/17/2017].

Smith, K. (2016). 58 Incredible and interesting Twitter stats and statistics. Brandwatch. https://www .brandwatch.com/blog/twitter-stats-and-statistics/ [06/17/2017].

Smith, K. (2019). 58 incredible and interesting Twitter stats and statistics. New York, NY: Brandwatch. URL: https://www.brandwatch.com/blog/twitter-stats-and-statistics/ [06/17/2017].

Sugimoto, C.R., Work, S., Larivière, V., \& Haustein, S. (2017). Scholarly use of social media and altmetrics: A review of the literature. Journal of the Association for Information Science and Technology, 68(9), 2037-2062. doi: 10/gbtnkr

The New York Times Customer Insight Group. (2011). The psychology of sharing: Why do people share online? New York, N.Y.: The New York Times.

Tsou, A., Bowman, T., Ghazinejad, A., \& Sugimoto, C. (2015). Who tweets about science? 15th International Society of Scientometrics and Informetrics Conference, Istambul, Turkey.

Vosoughi, S., Roy, D., \& Aral, S. (2018). The spread of true and false news online. Science, 359(6380), 1146-1151. doi: 10.1126/science.aap9559

Vainio, J., \& Holmberg, K. (2017). Highly tweeted science articles: Who tweets them? An analysis of Twitter user profile descriptions. Scientometrics, 112(1), 345-366. doi: 10.1007/s11192-017-2368-0 Warren, M.E. (2017). A problem-based approach to democratic theory. American Political Science Review, 111(1), 39-53. doi: 10/f9wpxp

Wojcik, S., \& Hughes, A. (2019). How Twitter users compare to the general public. Pew Research Center. URL: https://www.pewinternet.org/2019/04/24/sizing-up-twitter-users/ [October, 10, 2020].

Wong, L.L.Y., \& Burkell, J. (2017, July). Motivations for sharing news on social media. Proceedings of the $8^{\text {th }}$ International Conference on Social Media \& Society, 17, 1-5.

Woolston, Chris. (2014). Unusual reference attracts notoriety. Nature. URL: https://www.nature.com /news/unusual-reference-attracts-notoriety-1.16364.

Young, I.M. (2000). Inclusion and democracy. Oxford, UK: Oxford University Press.

Moscrop, David R.H., Wong, Lorraine, \& Alperin, Juan Pablo. (2020). Have You Seen This? Why Political Pundits Share Scholarly Research on Social Media. Scholarly and Research Communication, 11(1): 0101355, $21 \mathrm{pp}$.
Scholarly and Research Communication

VOLUME 11 / ISSUE 1 / 2020 